national collections, which would serve as the basis for a national system, in which museums of general cultural and archæological interest dovetailed with a grouping of auxiliary museums of localised or specialised function. That there is already a certain amount of co-operation, localisation and specialisation in action is, of course, well known. The university museums, having special functions, would have a special place in such a scheme. There is at present, in fact, a certain amount of specialisation as between the museums of the various universities, the PittRivers at Oxford being the most conspicuous example. In one direction the way has been pointed out by Dr. R. E. Mortimer Wheeler, in his address when declaring open the Bishop Hooper's Lodging as a folk museum at Gloucester on October 10 last. A report of his address and of the opening ceremony will be found in the Museums Journal of December. Dr. Wheeler's most suggestive remark was that pending, or the pessimist might say failing, the institution of a national folk museum, the local museum should set about the collection of the material of local folk culture before it is too late.

\section{English Instrument Making}

AT a meeting of the Newcomen Society held at the Science Museum on December 11, a paper by Dr. R. S. Clay and Mr. T. H. Court on "English Instrument Making in the 18th Century" was read. As is well known, Mr. Court has contributed largely to the collection of scientific instruments in the Museum. Some of these had been arranged on the lecture table, and during the reading of the paper Dr. Clay used them to illustrate his remarks. In the eighteenth century, he said, England was fortunate in having a number of men who were not merely instrument makers but also men of scientific knowledge. Moxon, Senex, Short, Dollond and Nairne were all fellows of the Royal Society, and they and others such as Benjamin Martin, George Adams and James Ferguson. made advances in the construction of scientific instruments which placed English microscopes, telescopes, etc., in the forefront and caused them to be copied abroad. One important invention was that of Marshall, who introduced the method of grinding a large number of lenses together on a block with a spherical tool, another that of the method of drawing brass tubes on a steel mandrel by which tubes capable of sliding smoothly in one another for telescopes could be made. Cuff, it appears, first introduced an allbrass telescope as a commercial instrument. The invention of the achromatic lens by Dollond, the invention of the quadrant by Hadley, the improvement in dividing scales by Bird and Ramsden and the construction of reflecting telescopes by Short all contributed to the supremacy of the English instruments. The biographies of a few of the most famous instrument makers only are known. Short was one of the few who made money by his business; a good many others were at various times made bankrupt. The outstanding men at the end of the century were Jesse Ramsden (1735-1800) and Edward Nairne (1726-1806).

\section{Dr. R. A. Millikan and the Earth's Magnetic Field}

Ever since the time of Gauss, it has been assumed that the intensity of the earth's magnetic field is practically symmetrical. When attempting to find out the nature and distribution of the cosmic rays, Dr. Millikan has discovered that we must seriously modify our ideas about the earth's field. According to a report by Science Service, Washington, D.C., Dr. Millikan in a paper read at a meeting of the National Academy of Sciences at Charlottesville, Va., stated that the magnetic field extends into space for at least 10,000 miles and that the magnetic intensity is stronger on the side of the earth opposite to America. There is a greater effect on the cosmic ray intensity from the north magnetic pole to the equator in the region of India than there is in comparable latitudes in America. The Department of Terrestrial Magnetism of the Carnegie Institution of Washington has compared the magnetic variations on the surface of the earth with Millikan's results determined by cosmic ray intensities. It concludes that the variations of magnetism extend many thousands of miles into space. The earth's field appears to be lopsided.

\section{A Standardisation of Inefficiency}

In the World Economic Survey just issued by the League of Nations instructive statistics are given of the world production of electrical energy. Taking the average annual issue from 1925 until 1929 as 100 , the issue in 1932 was 119 , in 1933 it was 125 and in 1934 it was 138. Perusal of the Survey shows that in no other branch of industrial activity has such rapid progress been made during this period of great depression. World Power of October, in commenting on this, points out that the manufacture of plant does not increase pari passu with the demand for electrical energy. Part of the lag may be due to the great advances made in generating efficiency as a result of industrial research. This may have inspired a policy of caution among buyers of plant, and so they may be chary of placing new orders. It may be advisable to correlate technical research and new orders for electrical development, if overseas countries continue to protect inefficient installations by obsolete standardisation regulations. World Power states that scientific investigation is likely to receive a severe setback because research work will lack a world market for the products it improves. A secondary boom tends to develop in the sheltered manufacturing industries abroad, which receive added protection from the depreciation of the exchange. A number of foreign countries with depreciated exchanges are adopting plant and equipment regulations which give results much inferior to those obtained by research and the best technical practice. There is in fact a tendency towards standardising inefficiency, and this discourages scientific research.

\section{Modern Physics}

OF the series of pamphlets recently issued in Paris by Messrs. Hermann et Cie under the title "Actualites 
Scientifiques et Industrielles", six deal with physical questions. M. Jean Perrin, under whose direction the pamphlets dealing with atomistics are issued, is himself responsible for four entitled "Grains de Matière et de Lumière". The first is on the existence of the 'grains', that is, of atoms, electrons and photons, the second on the structure of the atoms, the third on the complexity of their nuclei and on their radioactivity, and the fourth on the changes which can be produced in them by bombardment. Prof. Joffé of Leningrad, who is dealing with the physics of solids, contributes a somewhat longer pamphlet, on semiconductors, the conductivity of which is due to a small fraction only of the valence electrons attached to their atoms. M. Y. Rocard presents the first pamphlet of the series on hydrodynamics and acoustics, on the statistical theory of fluids and the equation of state, by M. J. Yvon. Each pamphlet gives a concise and readable account of the present state of the subject with which it deals, and is written by one who has himself made distinct and valuable contributions to our knowledge of it.

\section{Radio Data}

A SEcond edition of "Radio Data Charts" by Dr. R. T. Beatty (Iliffe and Sons, Ltd. 4s. 6d. net) is to be welcomed, since the opportunity has been taken to extend its scope to cover the most recent advances in radio technique. The various abacs provided now cover wave-lengths down to five metres, while provision is made for audio-frequencies over the range 20-10,000 cycles a second. This publication contains a series of thirty abacs with explanatory notes and examples, by means of which many of the quantities required in radio-frequency work can be obtained directly without the necessity for laborious calculation. In addition to the means for obtaining the inductance, capacitance and reactance of coils and condensers at both audio- and radio-frequencies, charts are given for obtaining the efficiency and time constant of a grid leak and condenser combination, for designing coils to have a minimum radio-frequency resistance and for the design of attenuation circuits, to select only a few typical examples. The whole series of charts is printed in a clear and easily accessible form and will be found to be most valuable to engineers, experimenters and students dealing with radio-frequency work.

\section{Clough Memorial Research Fund for Geology}

Througr the generosity of Mrs. Clough, a fund was established in 1935 in memory of her late husband Dr. C. T. Clough, for the purpose of encouraging geological research in Scotland and the north of England. The north of England is defined as comprising the counties of Northumberland, Cumberland, Westmorland, Durham and Yorkshire. Under the terms of administration of the fund a sum of approximately $£ 30$ will be available annually. Applications for grants for the period April 1, 1936March 31, 1937 should state the nature of research to be undertaken, amount of grant desired, specific purpose for which the grant will be used and whether any other grant-in-aid has been obtained or applied for ; they should be in the hands of the Secretary, Clough Memorial Research Fund Committee, Edinburgh Geological Society, Synod Hall, Castle Terrace, Edinburgh, not later than February 1, 1936.

\section{Statistics of the British Cinema Industry}

AT the meeting of the Royal Statistical Society on December 17, Mr. S. Rowson read a paper entitled "A Statistical Survey of the Cinema Industry". When the figures disclose that in 1934 there were 957 million admission tickets sold for the sum of $£ 40,950,000$ (the average price of a ticket thus being $10 \cdot 3 d$.), and when one further considers the character and splendour of the modern cinema together with the fact that four out of every five people visiting the cinema pay not more than one shilling for a ticket, the cinema is shown to be as one of the sociological wonders of the century, meriting attention and investigation. Of the year's revenue from admissions, the Government claimed $£ 6,800,000$ in entertainment duty. The average weekly cinema attendance throughout the year is about $18 \frac{1}{2}$ millions. At the end of 1934 there were 4,305 cinemas in Great Britain, with an average of 900 seats in each. In the London postal area alone, there were 401 cinemas. Of the various districts Lancashire had the greatest number with 699, Midlands next with 585, and Yorkshire and district next with 534. North Wales had the smallest number with 62- as opposed to 259 in South Wales. In the London area there was one seat for every 14 of the total population; in the Lancashire area one to nine; in the eastern counties one to nineteen; in South Wales one to ten. Eliminating the population under 15 as infrequent cinema-goers - the number of persons per seat were: in London, 10.9 ; in the Eastern Counties, 14 ; in the Midlands, $9 \cdot 6$; in Yorkshire, 8.0; in Lancashire, $7 \cdot 0$; and in South Wales, $7 \cdot 6$. It will be seen from the foregoing that the problem of redundancy or overbuilding is now becoming serious.

\section{Food of the Bullfrog}

Mr. S. W. Frost had a bullfrog of $200 \mathrm{gm}$. under observation in a cage provided with a small pond ("The Food of Rana catesbeiana, Shaw", Copeia, No. 1 ; 1935). Its feeding capacity is amazing. During the summer it ate more than four hundred and twentyseven grams of food-more than twice its own weight -in less than five months. The artificial conditions may, however, have caused it to eat more than it would have done in natural surroundings. The food eaten included 56 amphibians (frogs, toads and salamanders), 63 insects (beetles, moths, caterpillars, grasshoppers and cicadas), slugs (Limax maximus) and birds. As an example, on June 23 it ate 2 Promethia moths and 8 other insects; June 24, 1 Promethia moth, 3 other insects and 1 nestling sparrow ( $18 \mathrm{gm}$.); June 25, 1 frog (6 gm.); June 16, 2 frogs (13.5 gm.). It has a curious method of accepting its food, preferring to take it under water; "sometimes it snatches a morsel of food on the bank of a stream or pond, but invariably jumps into the water and submerges it to swallow". 